\title{
SWOT analysis of potentials of diving tourism and underwater heritage in Croatia, Slovenia and Montenegro
}

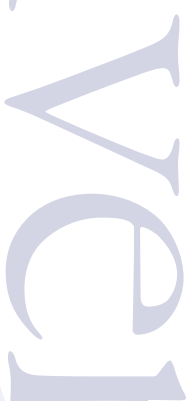

\author{
Ana Šilović, cultural tourism consultant
}

Namen pričujočega besedila je analizirati razvojne potenciale potapljaškega turizma na Jadranu, in sicer na destinacijah Izola, Mali Lošinj, Prvić in Budva. S pomočjo analize SWOT so v kontekstu splošnih pogojev opisane prednosti, pomanjkljivosti, priložnosti in pasti za razvoj trga za sodobni potapljaški turizem. Poseben poudarek je namenjen antični podvodni in drugi dediščini Jadrana ter njenemu potencialu, da postane edinstven del trženja potapljaškega turizma na Jadranu.

Ključne besede: potapljaški turizem, podvodna antična dediščina, destinacije, potapljači,Jadransko morje

The aim of this paper is to analyse potentials for development of diving tourism in Adriatic sea in destinations Izola, Mali Lošinj, Prvić and Budva. By using the tools of SWOT analysis each destination's strengths, weaknesses, opportunities and threats has been described in the context of general conditions affecting the development of contemporary diving tourism market. Special emphasis is given to the Adriatic underwater and other heritage from ancient period as to anylise its potential to become unique selling point of diving tourism in Adriatic sea.

Keywords: diving tourism, underwater ancient heritage, destination, divers, Adriatic sea

\section{Macro-Environment: Diving Tourism}

The world's largest broadcasting market for diving tourism is Europe where this segment of tourism is very well developed in most of the countries. Diving from a very specialized activity has developed into one of the most popular water sports whose market is very well organized since most divers are members of diving clubs or centres making them easy target to marketing.

\section{Product Description And Tourist Profile}

Diving tourism is a niche in the sports / adrenaline tourism market and refers to those trips which main purpose is diving involving also a large range of recreational diving activities.
According to the PADI (Professional Association of Diving Instructors), 2/3 of all European divers are men, highly educated with high-income, active, healthy lifestyle advocates whose usual diving trip takes io days.

Among divers' tourists we differentiate 3 market segments:

\section{Recreational divers}

This is the largest segment that accounts for about $70 \%$ of all European diver's tourists. This type prefers a combination of diving and non-diving activities in the destination where besides attractive underwater locations, comfort, culture, quality food and an attractive non-diving program, such as sports activities or cultural events, are also important. Passengers in this segment spend $40-50 \%$ of their travel in 
non-diving activities. About 50\% wear their own equipment.

\section{To attract this tourist profile the destination must have diving centers with high quality equipment, comfortable accommodation, good food and an attractive non-diving pro- gram.}

\section{Passionate divers}

This segment encompasses about $20 \%$ of the European diver's tourists and consists of diving divers who own a diving course or have a license. $2 / 3$ are men, married and between 46 and 55 years old and travel alone or with other passionate divers. The main motive of their trip is diving, ie the uniqueness and specificity of the submarine destination. When they are in the destination they dive as often as possible and do not over-invest in accommodation as well as alternative activities and offerings. Most wear their own equipment except cylinders.

The most important for these profile is the uniqueness and quality of the diving sites and the destinations so marketing should be based on the specifics of destination's submarine, with a detailed description of all underwater locations. Most of these divers believe in the oral recommendations of other passionate divers, so consider the option of web site editing and diving.

\section{Families and couples}

This segment comprises about IO\% of all European diver tourists. It is usually an enthusiastic diver and one who occasionally dives or who is not a diver at all. To this segment is of great importance the quality of the tourist offer in the destination and they are generally more inclined to spend on the quality of transport, accommodation and other additional activities. Families often prefer a swimming pool within the accommodation.

In this target segment, the focus should be given to the quality of the overall tourist package. What does not necessarily mean luxury. This segment generally requires a higher value than a low-budget option. The needs of non-divers d. accommodation with more recreational / entertainment facilities such as wellness or yoga classes should also be taken into the account.

\section{Product Specification}

The following product specifications are important for European diving tourists:

- high standards of equipment to be rented

- ecological sustainability of underwater locations

- detailed description and characteristics of underwater locations

- an attractive selection of non-diving activities in the destination that are appealing to divers such as: water skiing, tennis, golf, cycling, climbing, nature leave

- international diving club/centre certificates

- insurance

\section{The Biggest Emitive Markets For Scuba}

Tourism In Europe

- UK

- Germany

- France

- Italy

- The Netherlands

- Spain

- Poland

- Belgium

- Sweden

- Bulgaria

- Switzerland

- Romania

- Austria

PADI certified divers make up $70 \%$ of the overall diving tourism market. There are about 
3.2 million people and every year 826,000 are on their way.

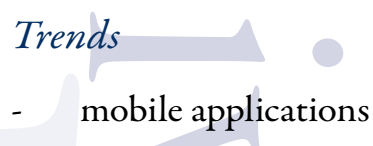

diversification of products (eg diving in glaciers or underwater photography courses)

\section{Benchmarking Analyses Of Main Competing Destinations To Adriatic}

Table I

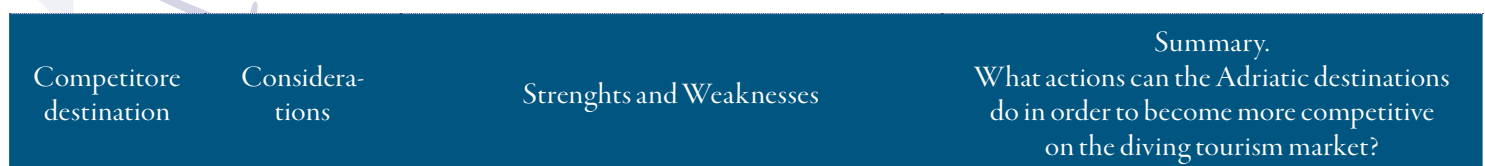

\begin{tabular}{|c|c|c|c|}
\hline Egypt/Red Sea & Seasonality & $\begin{array}{l}\text { Strengths: All year destination. Water } 15{ }^{\circ} \mathrm{C} \text { in Jan } \\
\text { to } 29^{\circ} \mathrm{C} \text { in September. } \\
\text { Weaknesses: None. }\end{array}$ & \multirow{8}{*}{$\begin{array}{l}\text { Egypt and the Red Sea offer a relatively inexpen- } \\
\text { sive medium-haul location from the main Europe- } \\
\text { an dive markets. Their main strengths include the } \\
\text { unique variety of Red Sea wildlife and an impressive } \\
\text { array of ship wrecks. This destination is home to } 3 \text { of } \\
\text { the top ten dive sites in the world. } \\
\text { Disadvantages include the additional time and costs } \\
\text { of travel when compared to European destinations } \\
\text { and relatively expensive costs for equipment hire. } \\
\text { A review of reviews (http://www.tripadvisor.com) } \\
\text { highlights some negative feedback about the lack of } \\
\text { a personal' approach from some of the dive schools. } \\
\text { Divers have suggested that the focus of some } \\
\text { schools is to fill boats and find sites that are suitable } \\
\text { for all levels of divers and } \\
\text { snorkelers, possibly limiting opportunities for more } \\
\text { experienced divers to try more challenging dives. } \\
\text { Given the range of aquatic life and quality of many } \\
\text { of the dive sites, the Red Sea is likely to remain a } \\
\text { popular competing destination in the long-term. } \\
\text { The Adriatic and its diving centres can be compet- } \\
\text { itive in quality of service and focus on personalized } \\
\text { service that targets individual diver's expectations } \\
\text { and is less focused on numbers. } \\
\text { Possibilities are bigger for shorter trips throughout } \\
\text { the year because the Adriatic is far from the broad- } \\
\text { cast market for up to } 2 \text { h of flying. } \\
\text { Possibilities for improving diving sites or setting up } \\
\text { new wrecks would increase the competitiveness of } \\
\text { the destination. } \\
\text { It is recommended to emphasize the wealth and va- } \\
\text { riety of non-diving offers in destinations particular- } \\
\text { ly of natural and cultural heritage. }\end{array}$} \\
\hline & $\begin{array}{l}\text { Quality } \\
\text { of dive sites }\end{array}$ & $\begin{array}{l}\text { Strengths: Excellent variety - includes Thistlegorm } \\
\text { Wreck (sunk 194I) and ranked } 4 \text { th most popular } \\
\text { dive site in the world. } \\
\text { Weaknesses: wreck sites are particularly prone to } \\
\text { archaeological theft - destroying the integrity of } \\
\text { some sites. }\end{array}$ & \\
\hline & $\begin{array}{l}\text { Aquatic life } \\
\text { and variety }\end{array}$ & $\begin{array}{l}\text { Strengths: Large variety of fish and plant species } \\
\text { - just under } 20 \% \text { are endemic to the Red Sea, pro- } \\
\text { viding a relatively unique marine life compared to } \\
\text { Mediterranean destinations that host more gener- } \\
\text { ic species. } \\
\text { Weaknesses: None. }\end{array}$ & \\
\hline & $\begin{array}{l}\text { Prices } \\
\text { (divebooker. } \\
\text { com) }\end{array}$ & $\begin{array}{l}\text { Strengths: There are numerous hotels in the Red } \\
\text { Sea that specialise in dive tourism and which pro- } \\
\text { vide competitive package prices that include } \\
\text { flights/hotel and diving tuition/equipment. } \\
\text { Prices: } \\
2 \text { dives with an instruction/ one day-30-35€ } \\
\text { Io dives with instruction / } 5 \text { days I20-175 } € \text {. } \\
\text { Equipment rental-10-20 } € \text { per day. } \\
\text { Cheaper than the Adriatic. }\end{array}$ & \\
\hline & $\begin{array}{l}\text { Distance from } \\
\text { outbound mar- } \\
\text { kets }\end{array}$ & $\begin{array}{l}\text { Strenghts: Good flight connections with majority } \\
\text { of European markets. } \\
\text { Weakness: } 4-6 \text { h by plane from } 4 \text { main European } \\
\text { outbound markets. Approx i to } 2 \text { additional hour's } \\
\text { flight time. More expensive destination for travel. }\end{array}$ & \\
\hline & $\begin{array}{l}\text { Distance } \\
\text { between dive } \\
\text { sites }\end{array}$ & $\begin{array}{l}\text { Weakness: } \\
\text { Linear coastline - tourist could be isolated when } \\
\text { there - large distances between dive sites. }\end{array}$ & \\
\hline & $\begin{array}{l}\text { Popularity } \\
\text { with main } \\
\text { European } \\
\text { Outbound } \\
\text { Markets }\end{array}$ & $\begin{array}{l}\text { Strength: Identified as number one destination of } \\
\text { choice for French and British divers. Second desti- } \\
\text { nation of choice for German and Italian divers (af- } \\
\text { ter the Maldives). }\end{array}$ & \\
\hline & $\begin{array}{l}\text { Quality of } \\
\text { non-diving } \\
\text { tourist offer }\end{array}$ & $\begin{array}{l}\text { Strength: Unique natural and cultural landscapes. } \\
\text { Weakness: Dive sites isolated from heritage fea- } \\
\text { tures requiring significant excursions. }\end{array}$ & \\
\hline
\end{tabular}




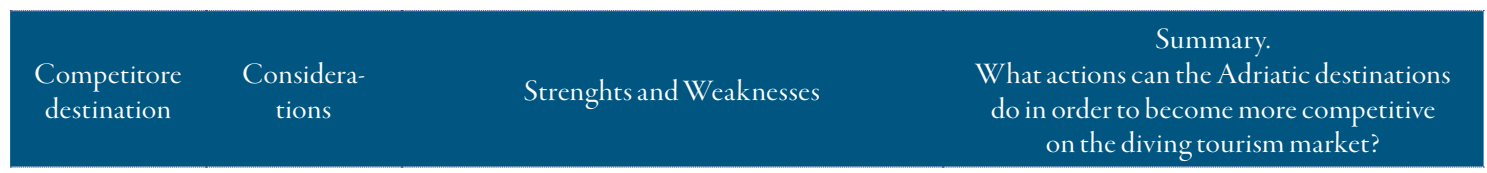
$\begin{array}{ll}\text { Seasonality } & \text { in September. } \\ \text { Weaknesses: No one. }\end{array}$
Strength: Excellent variety - includes The Zenobia
Wreck (a RO RO boat that sunk in 1980) and
sites ranked the best dive site in Europe.
Weaknesses: No one.

Strength: Diverse. Currents flowing from the Red and Black Seas bring a large diversity of differing Aquatic life marine life including Grouper, shoals of Double and variety Banded Bream, Stingrays, Scorpionfish, Amberjacks and Wrasse. Weaknesses: No one.

Weaknesses: More expensive then other Mediterranean destinations.

Prices

(divebooker.

Prices:

com)

2 dives with an instruction / one day-65-85 $€$ Io dives with instruction / 5 days-250-400€

Equipment rental $-20-30 €$ per day

Distance from

outbound mar-

kets

Weakness: In comparison with Adriatic add 2 more hours to flights from main otbound markets.

Distance between dive sites

Strength: Possible to visit most of dive sites in 7 days.

Popularity with main European Outbound Markets

Quality of non-diving tourist offer Stren
kets.

Strength: Very popular with main outbound mar-

Strength: Comparable with Adriatic. The island offers a range of holiday accommodation, beaches and resorts as well as a rich cultural history including numerous fortified settlements.
As a Mediterranean diving destination, Cyprus competes for the same outbound diving tourism markets. Its proximity to the Red and Black Seas provide a diverse marine life and provides a comparable array of 'non-diving' family attractions including beaches and urban cultural tourism.

Cyprus provides comparable water temperatures and experiences, although boasts wreck dive of international significance - the Zenobia.

The Adriatic may be competitive in its geographic position as it is closer to the emitting markets (the possibility of shorter stays during the year-offer weekend diving trips) as well as its variety of accommodation facilities and non-diving offers.

\section{-}

$\checkmark$

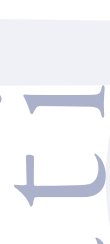

(

1

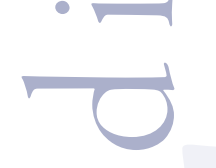

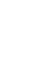




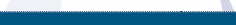

Competitore

destination

Considera-

tions

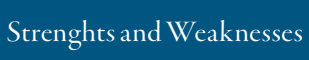

Summary.

What actions can the Adriatic destinations

do in order to become more competitive

on the diving tourism market?

Malta Seasonality Strenghts: allyear season

Quality of dive
sites $\quad \begin{aligned} & \text { Strenghts: Great natural diversity with a large num- } \\ & \text { ber of ship wrecks. Island Gozo has been at the top } \\ & \text { of the best diving destinations in Europe for years. } \\ & \text { Two locations (Blue Cave at Gozo and Cirkewwa) } \\ & \text { are among the top io in Europe. }\end{aligned}$

Aquatic life and Strengths: Much of the maritime belt is protectvariety ed, which contributes to the great variety of underwater life.

Strengths: Cheaper than the Adriatic. With emitting markets, it is also associated with low-cost airlines, which further reduces the way.

Prices:

2 dives with an instruction / one day-46-60€ Io dives with instruction $/ 5$ days-210-300 $€$

divebooker. com)

Equipment rental-20-30 € per day

Distance from

outbound

markets

Distance

between dive

sites

Popularity with main European

Outbound

Markets

Quality of non-diving tourist offer
Strengths: Close to all broadcasting markets (UK, Germany, Italy, France)

Strengths: The size of Malta allows any of the localities to be available in one day and several attractions can be visited at the same time.

Strengths: The most popular diving destination in Europe. $27 \%$ of its GDP comes from diving tourism. The most popular diving destination in the UK market (on Malta English is the official language).

Strengths: a rich cultural heritage that is a blend of diverse cultures that ruled the Mediterranean. Particularity is the large amount of sacral architecture ( 365 churches). Good beaches. Well-developed tourist infrastructure. Good night life.
Malta positioned itself on the tourist diving map as the destination for the most submersible ships. Its natural base (in the history of the sea, Malta has often been the scene of historic maritime battles and has undergone a lot of ship wrecks) has upgraded it with a large number of deliberately submerged ships recognizing the significance of this type of tourism. The specificity of Malta is much higher than the number of dives from the coast, but because of the fact that most of the sites at lower depths and built infrastructure have access points.

On an island that is smaller than Brač there are 34 diving centers.

Adriatic opportunities: introduction of no-take zones where diving, sailing of ships is allowed. Emphasize the diving specificity of the Adriatic in relation to other destinations. Creating an all inclusive package for divers during which it is possible to visit several destinations on the Adriatic for diving. 


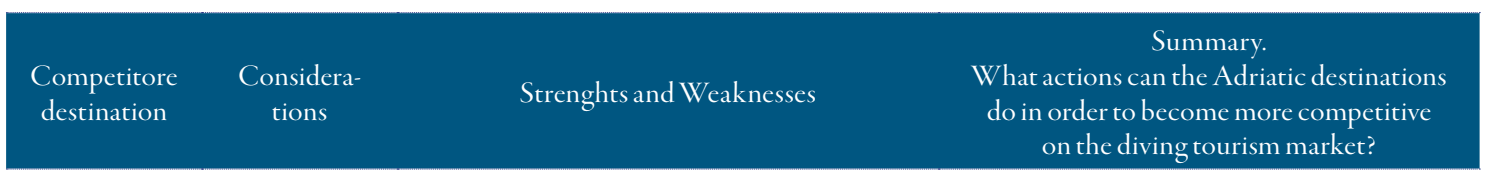

Strengths: In the south of Spain (Canaries, Granada, Malaga, Cadiz) the diving season lasts for $\begin{array}{ll}\text { Spain } & \text { Seasonality } \quad \text { whole year, while in the north (Cantabria, Gali- } \\ \text { ciarias, Basque) the season lasts about 6-7 }\end{array}$ months.

The main season of diving lasts from April to November.

Strengths: Great natural diversity with a large number of marine reserves (Cabo de Palos, Cabo de Gata and the Columbretes Islands on the Mediterranean and La Palma, La Resting and Isla Gracios Quality of dive on the Canary Islands in the open Atlantic). There sites is also a large number of wrecks (Don Pedro near Ibiza at $142 \mathrm{~m}$ is the largest ship wreck in the Mediterranean). The Canaries (Lanzerot) has a first class and unique attraction; Atlantic Underwater Museum opened in 2016.

Strengths: A great variety of flora and fauna with the possibility of encountering dolphins, whales, Aquatic life and turtles, and marine dogs. A large number of corvariety al areas. The most renowned diving destinations are mostly marine protected areas which enable the great wealth of marine flora and fauna.

Strengths: The largest and most famous diving centers work with large hotel chains and offer all-inclusive diving packages at affordable prices ( $\mathrm{eg}$ on the Costa del Sol) as well as many more affordable Prices diving rates for advance booking or family pack for (divebooker. com) courses diving $(3+\mathrm{I}$ free $)$. Prices:

2 dives with an instruction / one day-50-60€ Io dives with an instruction $/ 5$ days-200-300 $€$ Rent equipment - 18 - $30 €$ per day

Prices are similar to those of the Adriatic.

Strengths: Very good connection to airline lines Distance from with all broadcasting markets throughout the year $\begin{array}{ll}\text { outbound mar- } & \text { Weaknesses: Southern destinations and Canar- } \\ \text { kets } & \text { ies are about 2-3 hours distant from the Adriatic S }\end{array}$

ies are about 2-3 hours distant from the Adriatic Sea compared to the broadcasting market.

Popularity with main European Outbound Strengths: One of the most popular European diving countries. Canaries and Balearic has for years Markets been ranked among the best diving destinations in Europe.

Quality of non-diving tourist offer

Strengths: Tourism Superpower with world-famous gastronomy and the second by UNESCO locations. Known for its vibrant nightlife.

Spain is the tourismt superpower that recognized diving tourism as a special niche and consequently develops a specialized offer for divers. A number of popular diving destinations all year round connect to the airplane with broadcasting markets. The most famous diving destinations are the Canaries, the Balearic Islands, the Costa Brava and the Costa Blanca.

Adriatic Opportunities: creation of underwater diving parks, underwater archaeological parks, flooding boats.

Creating all inclusive diving packages.

1

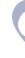
1

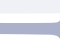
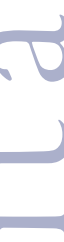
Turkey

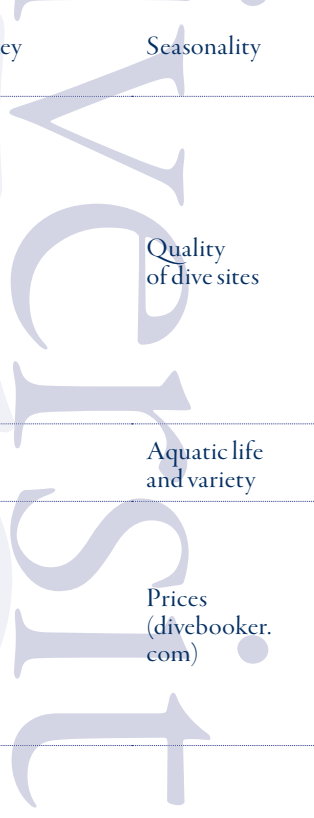

Distance from outbound markets

\section{Popularity} with main European Outbound Markets

Quality of non-diving tourist offer
Strengths: The season lasts from April to October with sea temperatures of 17 to $30^{\circ} \mathrm{C}$. The visibility is on average $30-40 \mathrm{~m}$

Strengths: A great variety of natural formations to submerged ships (over 125 submissive-oldest submersible ships in the world dating back to $\mathrm{I}, 400$ p.n.e.) to the great wealth of ancient sites. Gallipoli is the most famous destination for submersible ships (from WWI). There are a lot of amphora and other ancient ceramics in the Turkish underwater. Kas is the most famous Turkish diving destination due to the combination of natural caves (Blue Hole has been the most popular underwater site in Turkey for years), submerged boats and ancient sites.

Strengths: The diversity of the 4 must: Mediterranean, Aegean, Marble, Black.

Strengths:

Prices:

2 dives with an instructor / one day-30-70€

Io dives with an instruction $/ 5$ days-I35-300 $€$

Equipment rental-1o-2o€ per day

Diving prices are similar to those in the Adriatic,

but the prices of accommodation, meals, drinks and

shopping are cheaper than in the Adriatic.

Strengths: Some destinations such as Kas, Kalkan, Fethiya are close to the Antalya or Dalaman aerodromes that have direct links to most European cities.

Weakness: The Gallipoli airport does not have direct flights but it is in Istanbul. Turkey is generally more $\mathrm{I}-2 \mathrm{~h}$ away from the air market than the Adriatic.

Weaknesses: It is not yet positioned as a top diving destination on major outbounding markets. An unstable political situation.

Strengths: The destinations that are deployed as diving are mainly the kind of offer that this tourist profile prefers, and these are sports activities with an emphasis on adrenaline sports such as canyoning, rafting, paragliding, trekking, cycling, kayaking on the sea
Turkey is relatively a new diving destination that is rapidly evolving and where divers are recognized as a significant segment of tourists and this type of tourism is treated as a special niche. Rich flora and fauna, caves, vast variety of wrecks, reefs, sunken ships and aircraft and sunken ancient cities, as well as good visibility (20-40 $)$ contributed to diving in Turkey.

Every year, the number of underwater locations increases.

In most renowned diving destinations, most diving centers have international certifications such as PADI, SSI, CMAS. Most diving centers also function as tourist agencies, meaning that they offer full-service service to their guests in cooperation with various hotels and owners of accommodation facilities while some centers also own their own accommodation. There is also a large number of diving sites developed. Eg. Sundiving is a PADI diving resort with ${ }^{*}$ in Kasu offering all-inclusive packages and including a restaurant, bar and club.

Also, most diving centres offer diving schools in several languages, not just English.

Adriatic Opportunities: Positioning diving destinations by segment of guests (destinations for less and more technically demanding diving); creation of underwater archaeological parks; creating an all-inclusive package for divers; emphasis and creation of additional sports offer in diving destinations; an increase in the number of diving centres with international certifications. 


\section{Micro-Environment: Swot Analysis Of Diving Tourism In Atas Destinations}

\section{Introduction}

Given that there is no diving market for a closely specialized diving product such as the ancient underwater heritage, a SWOT analysis of the tourism potential of the destinations for the general product of diving tourism has been made, in relation to the general characteristics of this product and the profile of the European diver tourist mentioned in the previous chapter. Within this analysis, the resources of the ancient period, which form the backbone of the future diving thematic route of the Ancient Trap of the Adriatic Sea, are especially distinguished.

An introduction to the SWOT analysis of each destination gives a brief summary of the state of diving tourism in the country that represents a strategic framework for the development of this type of tourism.

In the analysis of the touristic / resource base of the destination, those segments / offers that are an integral part of the diving tourism products and which may be attractive for all three segments of this market are considered:

- the plant and animal world of the underwater world

- underwater locations - with particular emphasis on antique

- beaches, cultural heritage and manifestations - with special emphasis on antique; natural heritage; sports activities

In order to determine its positioning in relation to the major european emission diving markets destinations have been analysed regarding their tourism infrastructure, accommodation capacities, traffic accessibility.

\section{Slovenia - Izola}

Diving Tourism In Slovenia

Diving tourism in Slovenia is not recognized as a special type of selective tourism that has its market and the diving offer function as an additional sporting activity in destinations.
Umbrella organization for divers in Slovenia is SLOVENSKA POTAPLJAŠKA ZVEZA (SPZ), whose members are 60 diving clubs/centres. The main objective of the SPT is the professional training of members.

The promotion of diving tourism is in the domain of the National Tourist Office TZS, which does not distinguish diving tourism as a special and significant niche in tourist offer but is treated as an additional activity in destinations.

There is no legal regulation for diving (diving tourism and diving sports are not separated from other diving). National legislation that in other European countries allows for the development of diving tourism such as scuttling does. not exist and it is very difficult to obtain a license for such a thing. There is also no awareness of the introduction of no-take zones that do not allow any human activity except diving and are primarily directed to the preservation of a fishbased fund that makes the underwater more attractive for diving.

As far as diving standards and certification are concerned, most of the approximately ro diving clubs involved in diving services in tourism have international certificates. This facilitates the development of diving tourism as European tour operators specializing in this tourism sector work exclusively with those diving clubs that have international certifications .

Education of diving staff regarding the interpretation of underwater sites does not exist. The potential of multimedia technologies in the presentation of underwater sites has also not been used at all.

There are about Io diving clubs / centers in Slovenia, all of which offer diving (diving, excursions). Diving season takes about 3 months, from June till September.

Slovenia has not been recognized in the major broadcasting markets as one of the existing Mediterranean diving destinations and has not been included as a destination on some of the popular web services for the purchase of tourist diving services such as: scubatravel.com; scuba- 
travel.co.uk; divebooker.com; easydivebooking. com.

Also, most diving centres do not offer package deals.

\section{Izola}

Number of inhabitants: 14.549 (20I2.)

Resource And Attractive Base For Diving Climaté

The average summer temperature is $28^{\circ} \mathrm{C}$ and winter $5^{\circ} \mathrm{C}$. The average amount of sunny days is 300. The sea temperature is usually from the lowest $7^{\circ} \mathrm{C}$ in February to 24 in August.

According to climate predispositions, the diving season can last 6 months: from May to October with sea temperatures between ${ }_{17}-24{ }^{\circ} \mathrm{C}$. As it is currently 3 months from June to September, it can be concluded that the potential of diving tourism in pre-season and post-harvest is insufficient.

\section{Underwater}

\section{Flora and fauna}

The North Adriatic is particularly rich in fish endemic species. The reason for this is the karst morphology of coastal and underwater topography, including inhabited underwater habitats, karst rivers and spheres. There are 45 subtypes, the endemic of the Adriatic coast and the islands. There are about 410 species and subtypes of fish in the Adriatic, representing approximately $70 \%$ of Mediterranean fish taxa, with at least 7 species living only in the Adriatic. Because of the excessive fishing, about 64 known species are before extinction.

\section{Protected areas}

In Slovenia marine protected natural areas are Strunjan Nature Park (includes the sea and the sea coast), nature monuments Debeli Rtič and Cape Madon. All these areas are in the immediate vicinity of the destination. Strunjan $\mathrm{Na}$ ture Park ( $5 \mathrm{~km}$ from Izola) that was founded in 2004, covers 429 hectares and contains two natural reserves. The park consists of $4 \mathrm{~km}$ long cliff, the northernmost Mediterranean solana and the only Slovenian lagoon system. It is also the northernmost point on which some Mediterranean plants are grown. The Debeli Rtič Monument is comprised of 24 hectares and consists of a sea and coastal area. Nature Monument of Rt Madona comprise I2 hectares - Piranska Punta

\section{The Izola underwater is inhabited by the typ- ical flora and fauna of the North Adriatic. In the immediate vicinity of the destination there are 3 protected sea areas which have a beneficial effect on the natural resources of the underwater and the attractiveness of the diving destination.}

\section{Diving Sites}

For the needs of the SWOT analysis, the offer (presented on the web site) of 4 diving centers was explored: Sub-net (Piran); Dive strong (Portorož); Rex Maris (Koper); Sharky (Piran).

The offer of diving tourism includes the following diving sites:

Natural attractions: Ridge Fiesa; the ridge under the Pyrrhus church; the ridge on the Pire Point; underwater Triglav (the deepest point in SLO sea marked with $2500 \mathrm{~kg}$ of concrete pyramid on which Triglava's coat is); Bernardin

Flooded ships: KEC (military-transport ship-WW2.); Maona (WW2); FIESA

Ancient Locations: San Simon Archaeological Park

Antique Diving Sites

- San Simon Archaeological Park

- Remains of antique construction, Jernejev zaliv

Most of the underwater locations can be reached with the dive from the coast, so the arrangement of access points certainly would contributed to the development of diving tourism as well as better positioning of the destination on the diving market. 
Resource And Attractive Base For Non-

Diving Activities

Beaches

A total of 6 beaches, one of which is a beach for blind and disabled persons.

\section{Natural Heritage}

Postojna Pond $(66 \mathrm{~km})-5 \mathrm{~km}$ of underground tunnels, part of which is seen from the electric train. Near the entrance to the pit is the largest cave castle in the world, which is located in a 123 $\mathrm{m}$ high pit.

Škocjanske pige $(30 \mathrm{~km})$ - System of karst caves in Slovenia, protected as a Regional Parade (+ UNESCO), which are one of the world $>$ s largest natural phenomena as one of the largest underground canyons in the world.

Sečovlje Nature Park Salina $(3 \mathrm{~km}$ from Izola) was founded in 1990 and covers $72 \mathrm{I}$ hectares, and includes four natural reserves.

Nature Park of Jezera Fiesa 2.I hectares, as the only coastal lake in Slovenia.

The Škocjan Inlet Natural Reserve was founded in 1998 and covers 122 hectares. This is a swampy area rich in bird species.

Cultural Heritage And Events

Parenzana Museum - Presented History of the Parenzana Railway, which was in the early 2oth century connects Trieste with Porec; Ship model museum; International Latin American Dance Competition - May; Istrian International Rowing Regatta - Jun; Izola Boat Show - September.

\section{Cultural Heritage Of Antiquity}

The ancient cultural heritage that is available for use in the field of tourism is only the archaeological park of Simon's Bay. An interpretation center and underwater archaeological park have been set up in the park. In addition, ancient heritage is also presented within museums. In Koper, Pokrajinski muzej Koper, within the framework of a permanent exhibition, exhibited and antique exhibits from the wider area. Part of the ancient heritage of the Slovenian coast and coast is also included in the permanent exhibition of Pomorski Muzeja Sergej Mašera Museum in Piran.

\section{Sport Infrastructure}

2 sports halls, 2 stadiums, 2 tennis clubs, a horse club, a rowing club, the cycling track "Pot of Health in Friendship" - former part of the Parenzana trail, turned into a cycling trail that stretches from Škofja to Seča and is largely decorated and marked.

\section{Other Attractions}

Casino Izola; Zdravilišče Strunjan - healing sea mud, a wide range of treatments like thalassotherapy.

Close to the destination there are several protected natural areas, two of which are among the largest natural attractions in Slovenia: Postojna and Skocjanska pits. Parenzana Museum is a unique cultural attraction as well as a cycling trail on the route of former Parenzana.

An additional offer from the field of active tourism would certainly increase the competitiveness of the destination.

\section{Traffic Accessibility Of The Destination}

\section{Traffic connection}

Izola is available on the road: Trieste (E6I), Zagreb (E70 / E6I), Budapest (E57, E70 / E6I)

Portorož Airport - Io km

Friuli-Venezia-Gulia Airport - $30 \mathrm{~km}$. Connected to a regular bus line with the airport.

Ljubljana Airport - $125 \mathrm{~km}$

\section{Emitive destination markets}

In 2008 (last available data) totalled 90.113 arrivals and 376,279 nights, of which 242,254 domestic guests and 134,025 foreign guests.

The most significant broadcasting markets with foreign guests are: Germany (22\%), Austria (I5\%), Italy (I2\%) and Belgium (I I \%), Switzerland and Sweden ( $5 \%$ ), Hungary and the Netherlands (4\% (3\%) and Czech Republic (2\%). 
From the existing guest structure it can be concluded that Izola is primarily a road destination for its largest emission markets. The largest European emittive markets for diving tourism are: Germany, UK, France, Austria, Scandinavia. In addition to UK, all these markets are already the emitive market for destination, which facilitates the promotion of diving tourism. Also considering the geographic position of Izola and the road distance for certain markets (Italy, Austria, South Germany) there are favorable predispositions for the promotion of shorter diving holidays during the year.

Market activities in markets such as UK, Scandinavia and France will depend on air-

line seasonal and outbound connections.

\section{Accomodation Capacities}

By the last available data from 2008 Isola has: I. 433 rooms, 4.34I beds; II hotels $-24^{*}, 93^{*}$ $39.8 \%$ of overall accommodation capacities; 2 autocamps; I hostel; other accommodation (rooms, apartments) - cca 50\% of overall accommodation capacities.

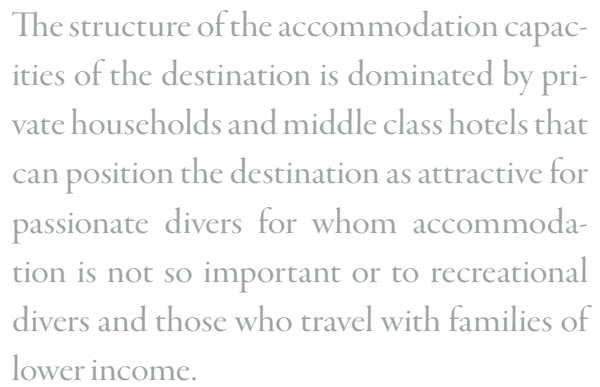

Table 2: SWOT

\section{STRENGHTS}

- good geographic position: road and airborne availability of broadcasting markets

- favourable climatic conditions

- clean, clear and safe sea (absence of dangerous marine species)

- close to many nature parks

- archacological underwater park

- a large number of protected areas on the sea

\section{WEAKNESSES}

- Slovenia has not been recognized as a diving destination on the emerging markets for diving tourism

- lack of quality hotel accommodation insufficiently developed offer of active tourism

legal regulations do not support diving

(non existence of no-take zones)

- a small number of archaeological sites prepared for sightseeing

\section{OPPORTUNITIES}

- raising the quality of accommodation capacities

- development of sport / active tourism

- the possibility of changing legal regulations regarding the sinking of ships and no-take zones

- the possibility of introducing new attractive services at diving centres: underwater photography courses, ....

- the possibility of introducing an al-inclusive package for divers

\section{Croatia - Island Of Lošinj, Island Of Prvić/Vodice}

\section{Diving Tourism In Croatia}

Diving tourism in Croatia is relatively developed although the Croatian Tourist Board has not recognized it as a special type of selective tourism that has its market so the offer functions mainly as an additional sporting activity in the destinations. Croatia has been partially recognized on major broadcasting markets as one of the Mediterrane-

\section{THREATS}

- ecological degradation of underwater (fish catch, illegal underwater fishing)

the growth of other diving Mediterranean destinations

-insufficient marketing activity in target markets

the lack of a clearly shaped tourist product

an diving destinations and has been included in some of its popular web services for the purchase of tourist diving services such as: scubatravel.com; scubatravel.co.uk; divebooker.com; easydivebooking.com. The biggest amount of Diving centres is presented at www.diviac.com (13). There is also description of diving destinations at www. padi.com as well as locations of PADI centres (19). Croatia is not presented as a diving destination at www.diveworldwide.com, www.liveaboard.com and in general liveaboard offer is issing. -gradual retardation of competition 
In general Croatian diving offer is insufficiently present and the country could be much better recognised as diving destination on the most important diving web sites and book services (only cca 10\% of Croatian diving centres only $40 \%$ of diving centres is presented at web sites of internationally recognised diving organisations like PADI and SSI).

The umbrella diving organization in Croatia is a Diving Association with 150 club members and I5o diving centers included. Diving Community in Economy at the Croatian Chamber of Economy was established in 2006 and its main aim is to regulate and promote diving tourism and consequently represents the main umbrella organization for diving centers, which, unlike diving clubs, are mainly used commercially, ie providing services in tourist-recreational diving. The aim of the Community is to unify diving regulations, to allocate diving tourism as a separate form of tourism through the new Tourism Services Act and to issue a Regulation on diving safety as well as to promote Croatia at specialized European diving fairs.

Initiatives have recently been launched to create the legal and other conditions that in other European countries allow the development of diving tourism such as deliberately scuttleing in order to gain new, interesting dive sites in areas that are otherwise unattractive to scuba diving. As a result of the lobbying of diving clubs and centers in Kvarner, a new spatial plan of the County of Primorje-Gorski kotar has drawn areas within which controlled shipwrecking will be allowed, and appropriate underwritten acts related to the sealing of ships will be developed and the County is preparing for the procedure concessions. In 2016 the first ship was soaked in Croatia in Pula near Cape Kamenjak, the flagship of JRM Vis, built in Uljanik and bought in Montenegro. The ship is owned by one Istrian entrepreneur. The obtaining of various permits and the struggle with administrative obstacles lasted 5 years.

In Croatia there are seven protected seas (NP, nature park, nature reserves): Brijuni and
Limski kanal along the coast of the Istrian peninsula; Kornati and Telascica in the middle Adriatic, near Sibenik; and the Lastovo Islands, the Malostonian Gulf and the Mljet Island in Southern Dalmatia. However, the level of protection does not automatically imply that those areas are no-take zones that are otherwise particularly attractive for diving due to the renewed ecosystem. Currently in Croatia, except in the small area of the NP Kornati and on the Brijuni there are no such zones that make the Croatian submarine less competitive in diving toursim due to the large fishery. NP Brijuni, Lim Channel and Telašica Nature Park are prohibited for diving.

In special zones / underwater locations it is not possible to dive or possess individual approvals. These are areas under the special protection of the Ministry of Culture and diving is only possible with the escort of a diver's diver from a licensed diving center (concession). $\mathrm{Na}-$ tional Parks Kornati and Mljet are controlled diving areas for which permits are issued by park administration.

As far as diving standards and certification are concerned, most of the centers have some of the international certificates: PADI, CMAS, SSI. Sometimes diving instructors in certain diving center have certification but the center is not certified by PADI or SSI and so it is not presented on their web sites.

Education of a diving staff on the issue of interpretation (narration) of underwater locations does not exist. The potential of multimedia technologies in the presentation of underwater sites has also not been used at all.

The diving season lasts about 4 months, from June till end of September. Most of the diving services are purchased during July and August when is high tourist season in Croatia confirming the fact that diving is mostly just one of the additional sport activities in the destination. Unfortunately, exact statistics and data for this aspect of tourist arrivals do not exist.

Diving centres mostly do not offer possibility of advance or online selling and booking but 
exclusively on the diving site. Also, most diving centers do not offer package deals.

Most diving centers offer the same services as: diving courses, renting equipment, boat trips, diving while SubSeaSon (Lošinj) offers a course offering underwater photography and underwater archeology course. DIVER and SubSeaSon (Lošinj) also offer diving programs for children.

\section{Island OfLosinj}

Number of inhabitants: City of Mali Lošinj 8244

\section{Resource And Attractive Base For Diving}

\section{Climate}

Lošinj has a moderately warm climate with the hottest month of July, which has a moderate temperature of $24.5^{\circ} \mathrm{C}$ and the coolest fastener at $7.7^{\circ} \mathrm{C}$. Average daily temperatures above $20^{\circ} \mathrm{C}$ can be expected from the beginning of June to the end of September. The sea temperatures range from mid-June to the end of September by more than $20^{\circ} \mathrm{C}$, so it is pleasant to bathe during that time until the winter temperature drops to $90 \mathrm{C}$.

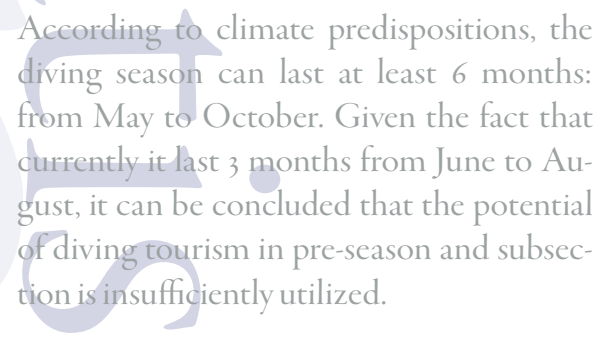

\section{Underwater}

Because of the marked indentedness of the sea that moors the shore of the islands, underwater is rich in plant and animal life. The constant flow of the sea between bays and coves gives the sea a pronounced clarity and clarity, purity and transparency. There are II 2 species of fish in the sea (of which 30 are endemic species), 7I species of tens of thousands of crabs, shellfish, snails, various kinds of shrubs and thistles. Dolphins are frequent visitors to this area, unlike some of the neighboring countries where they have com- pletely disappeared. The community of good dolphins that inhabits the sea around Cres and Lošinj counts 200 dolphins. Major scientific reasearch interest of Blue World Institute of Marine Research and Conservation from Lošinj is precisely study of common bottlenose dolphins in the Adriatic sea so we can say that Losinj dolphin today is one of the best explored marine vertebrates in the whole Mediterranean. Sea turtles can also be seen along with dolphins in Lošinj underwaters.

$$
\begin{aligned}
& \text { The Losinj Reserve for Good Dolphins with } \\
& \text { its } 526 \mathrm{~km} 2 \text { is the largest protected area in } \\
& \text { the Adriatic Sea and it is the first reserve in- } \\
& \text { tended to protect one dolphin population } \\
& \text { throughout the Mediterranean. Within } \\
& \text { the area there are I52 species of marine flora, } \\
& 303 \text { species of marine invertebrates ( } 7 \text { strict- } \\
& \text { ly protected, } 9 \text { protected) and Irz species of } \\
& \text { fish (of which I9 are endangered in Croa- } \\
& \text { tia). The area is also known as a place of ex- } \\
& \text { ceptional archaeological significance be- } \\
& \text { cause here it has bben found a Greek statue } \\
& \text { in bronze that represents an invaluable repli- } \\
& \text { ca of Lysipi's Apoksiomeon. These features } \\
& \text { make Lošinj's aquarium extremely attrac- } \\
& \text { tive for scuba diving. }
\end{aligned}
$$

\section{Diving Sites}

Diving centers in the area of the island (4) offer visits to locations in the wider Lošinj aquatorium.

Natural attractions: the walls of the island of Suska, Unija, Zeča and Cutina with their Red Gorgonians; 'Cathedral' cave system at Premuda; wall and cave on Srakane Island; the wall of the Zebulunite; Guilt.

Flooded ships: Etnea / Tihany (1917); Amsterdam; St. Stephen (1914)

Ancient Locations: An Apoksiomeon Statue; remains of amphora near Wolff Tihany; archaeological remains near Susak.

Underwater Historic Park Losinj is located within the diving center DIVER - LOŠINJ in Čikat bay. The park setting consists of II different exhibits that testify to the rich history of the 
island and its region, set at a depth of 5 to $15 \mathrm{~m}$. Among the exhibits are replica of XVI century guns, antique amphora replica, ants from the 4th of the sth century, Venetian cannons, gunners from II. world war, and the biggest attraction of the underwater park is certainly the replica of the antique bronze statue of the athlete Apoksiomeon from the 2 nd to the ist cent. before Christ, a symbol of Mali Lošinj. The Apoksimeon replica is erected in an upright position in natural size, and the entire path to the park is about $300 \mathrm{~m}$.

\section{Ancient Diving Sites}

Sites under protection of Ministry of culture RC:

- Ancient Shipwreck, Z-47, Ilovik Island

- Ancient Shipwreck, Z-36, Unije Island

- Antique shipwreck with cargo, Z-49, Lošinj Island

- Ancient Amphora, Z-48, Losinj Island

- Ancient ceramics and building material of Z-77, Osor

- Antique shipwreck with load of construction material, Susak Z-22

- Ancient Shipwreck, Pernat, Z-37, Cres Island

- Antique Shipwreck, Martinšćica, Z-i 4, Cres Island

The Lošinj submarine is characterized by the richness of flora and fauna and the diversity of underwater locations, the most significant of which are natural attractions. Premuda 'Cathedral' is among the top io diving sites in the Adriatic. Finally, there is a wreck of St. Istvan (1914), which is the largest and most famous ship in the Adriatic, but at a depth of $66 \mathrm{~m}$ and is only available to the most experienced divers. Its shift to a lower depth would significantly contribute to the greater attractiveness of the diving on Lošinj.

Ancient sites have a fair number, but none of the diving clubs have a concession (high price) so not all are included in the tourist offer.
The Underwater Historic Park is the only attraction in the Adriatic and especially attractive for children and less experienced divers. It is one of the top io locations in HR for diving on

http://www.boatinternational.com/destinations/mediterranean-yacht-destinations/ of-the-best-dive-sites-in-croatia--33I49/ frame-IO

Resource And Attractive Base For NonDiving Activities

Beaches

There are altogether 50, 4 of which are sandy. 3 beaches have a blue flag. Beaches represent one of the key resources of the island, and by their number and diversity they open up the possibility for much more significant valorisation.

\section{Natural Heritage}

The specificity of Lošinj is a great wealth of plant species. According to research, IOI8 plant species have been identified, of which 939 species belong to indigenous flora. Of these, 230 species belong to medicinal herbs.

There are 2 forest parks: Čikat and Pod Javori.

\section{Cultural Heritage And Manifestations}

The protected cultural and historical part of the town of Mali Losinj and the Osor settlement are some sort of outdoor museums rich in cultural heritage of various historical styles. Nearby are 2 archaeological zones Oruda and Palacol.

The museum gallery of Veli Losinj reveals a rich naval tradition of the island. The permanent exhibition has the task of presenting the layered history of Lošinj, with a special focus on the famous naval past.

Osor Music Evenings - an international festival of classical music during July and August.

Jazz Festival Losinj - The central music event of Lošinj's cultural summer is held in July. The festival is of international character. 
Cultural Heritage And Attractions From Ancient Period

The Apoksiomeon Museum is a unique cultural phenomenon in Croatia. It is dedicated to an antique bronze statue that is the only such proportion found on the eastern Adriatic coast (at a depth of $45 \mathrm{~m}$ ). It was dated 2 nd or Ist st.p.k. And from 8 so far known variations of Apoxyomenic prototype, the Lošinj statue is the most complete and most conservative.

There are tourist guides specialized in ancient times in Lošinj that are educated and certified for professional management on the subject of "Lošinj in antique times".

From this year there is also a unique manifestation of the Apoksiomeon Festival and Antiquity (May) during which visitors can experience and try different services and products inspired by Apoxyomen and Antiquity: antique antiquing sailing, diving in archaeological sites, Apoksiomen's Natural Cosmetics, Apoksiomen's Massage, Apoksiomen's Cooking School, workshops with antique wines ...

Osor - Archaeological collection of Osor and several archaeological remains in situ: ancient walls, fortifications, early early Christian basilicas.

\section{Othel: Attractions}

Lošinj Education Center on the Sea - the first educational interpretation center on the sea on the Adriatic coast, founded in 2003 by the Blue World Institute for Research and Protection of the Sea with the aim of disseminating information and educational content on biology, research and threats and protection of the marine ecosystem to a greater number of people. The center has a large number of its contents dedicated to education of children.

The turtle recovery site - is located in the Sunny Bay in Mali Lošinj and in the interest of the Institute for Research and Protection of the Blue Sea. It is the only recovery site along the coast of the Adriatic Sea. For turtles, various lectures are organized for visitors, and the biggest attraction is the public launch of sea turtled marine turtles.

\section{Aquapark Cikat}

The Day of the Dolphin - held on I July, consists of lectures, exhibitions, workshops, games, sports competitions etc. One of the main features of the Dolphin Day, where this event became recognizable, is the great international art exhibition of children's art on the sea and dolphin theme Sea turtles world day - 16.06. - is marked by a series of workshops and activities aimed mainly at children

Sport

On the island of Lošinj you can hike and hike to $250 \mathrm{~km}$ of landscaped stretches that stretch to five islands, include areas on the island of Cres (Punta Križa) and on the islands of Lošinj, Ilovik, Susak and Unions. The trails are diverse from light to foot to middle and very demanding hiking trails.

Losinj still has the following sports facilities: outdoor tennis courts (27), multipurpose playground (small football, 2 basketball courts, 2 tennis courts, 2 volleyball courts), beach volleyball, boccia, mini golf, table tennis, bowling alley, outdoors, 30 directions for free climbing on natural rocks, cycling trails, sailing, kayaking.

\section{Sports events}

4 Islands MTB Stage Race - Unique mountain-bike race on four islands: Rab, Krk, Cres and Lošinj. Beautiful and picturesque landscapes, great organizations have put this race into the calendar of many MTB enthusiasts, which is not surprising since the race was declared one of the best in Europe.

Downhill Lošinj (cycling) - extreme bicycle racing downhill

Lošinj-Cres Trail - A 2-seater stage racing track that takes place in October.

Lošinj semi-marathon - is held in September.

The regatta of the Losinj Olympics - two days, every year in August 
Nerezine regatta of traditional sailing boats - Sailing regattas of wooden treasures in Nerezine began in the late 1920 .

Lošinj's regatta on the rocks in September

New Year's Cup of Nations and Cities in Underwater Fishing - It's been held since 1959. The 56-year-old underwater fishing competition has been recognized as one of the most prestigious and amongst the most powerful in the world. The data that you have done and participated in this competition is a matter of honor and prestige of every underwater fisherman in the world.

\section{Thanks to the beneficial influence of the sea and the medicinal herbs, Lošinj was declared a climatic health resort in the 19 th century, so accordingly the island se- lected the positioning in the tourist mar- ket under the slogan "Island of vitality", which significantly developed the offer of active tourism. This tourist offer can be extremely appealing to tourists-divers who are focused on a healthy lifestyle and are prone to practicing just sports activi- ties on vacation. \\ Lošinj's specialty is also a large number of in- ternational sporting events that have a great tourist potential and affect the season's ex- tension and can certainly be interesting for divers-tourists.}

The specialty of Lošinj is also a large number of unique attractions and events related to the sea and sea life such as the sea education center, the turtle recovery or the Dolphin Days and the celebration of the World Day of Sea Turtles making the island extremely attractive for the segment of divers traveling with families.

The Lošinj city administration and TZ thanks to the unique Apoksiomeon attraction have recognized the poetry of antiquity for branding the destination and launched a series of activities for the purpose of creating a new tourist product, which certainly facil- itates the development of diving tourism on antiquity.

\section{Accomodation Capacities}

70 accommodation facilities with 20,080 beds, of which 9 hotels, 2 tourist resorts, 9 boarding houses, 7 campsites and 3 hostels, while other family accommodation. In the structure of accommodation capacity dominated by camps with $44 \%$ share, followed by family accommodation of $27 \%$ and hotels with $12 \%$. Of 9 hotels $22 \%$ have $5 *$ (2 hotels), $56 \% 4 *$ ( 5 hotels) and $22 \%$ $3^{*}$ ( 2 hotels).

A large number of accommodation facil ities in camps can be interesting for divers to tourists who like to travel low budget like passionate divers.

A large number of high-class hotels can attract segments of the recreational dive market and those who travel with families who generally have high income research and prefer high-quality or luxurious accommodation. A large number of hotels also point to favorable opportunities for the formation of tourist products in pre-season and post-season.

\section{Accessibility OfDestination}

\section{Traffic connection}

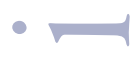

Mali Lošinj Airport-at the moment accessible only for private airplanes and charters. In 2018 it is planned reconstruction of the airport with the extension of the piste that will allowed international flights.

Airport Krk - $80 \mathrm{~km}$ from Lošinj. Flights to: Zagreb, Koln, London, Stockholm, Bucharest. Stuttgart, Dusseldorf, Tel Aviv, Košice, Riga, Moscow, Munich, Innsbruck, Gothenburg. Significantly fewer flights out of season. 
Road distance

Lošinj is available in the markets of Italy $(\mathrm{SJ})$, Austria, Slovenia and Germany (J) within 3-6h driving.

\section{Emitive destination markets}

In 2015, I,827,232 overnights were realized and $89 \%$ were foreign and II \% of domestic tourists. In the arrival of foreign tourists, Slovenes (27\%), Germans (23\%) and Italians (16\%) are the most numerous. The dominant form of tourist transport is a car (70\%), followed by a bus (13\%) while the share of other means of transportation is negligible.
The largest European diving markets are: UK, Germany, France, Italy, the Netherlands, Poland, Sweden.

Of these, Losinj has been positioned as a very popular tourist destination on the German, Slovenian and Italian market, which facilitates the promotion of diving tourism in these markets. The road availability of these markets enables the marketing of marketing activities to a diving product of short breaks throughout the year.

With regard to airline connections it is possible to set up as a target market for UK and Sweden on long-term.

Table 3: SWOT

\section{STRENGHTS}

\section{WEAKNESSES}

- favorable climatic conditions

- attractive marine flora and fauna such as dolphins and sea turtles

- air and road accessibility of several emission markets

- developed diving tourism as an additional offer in the destination

- developed an additional offer such as underwater photography courses, archeology and diving for children

- ancient cultural heritage with a unique European attraction of the Apoksiomeon Museum

- destination Management on Antiquity

- the existence of attractions Underwater Historic Park

- the existence of hyperbaric chamber for emergency cases

- Croatia is recognized as a diving destination on the broadcasting markets

- significant number of underwater archaeological sites from the period of antiquity

- attractive brand: Island of vitality

- a large number of different attractions and contents for chil-

dren that can attract a profile of divers traveling with families

- variety of hotel accommodation facilities

- developed offer of active tourism
- low airborne out-of-season availability

- the absence of a no-take zone

- legal regulations do not support the development of diving (sewage ships)

- diving clubs are not willing to pay diving concessions at underwater archeological sites

- a small number of ship wrecks

- weak promotion and sales management- complete absence of marketing and sales of diving centres in terms of online channels
- international certification of bigger number of diving centres - diversification of diving offer

- introduction of a no-take zone

- the possibility of changing legal regulations regarding ship seizure

- the possibility of introducing new attractive services at diving centers

- development of diving centers in the direction of all-inclusive offers for divers or

creating special all-inclusive offers in cooperation with hotels - the introduction of new airline lines to the emerging markets
- ecological degradation of the underwater (fish catch) gradual retardation of competition the growth of other diving Mediterranean destinations -insufficient marketing activity in target markets the lack of a clearly shaped tourist product -inability to conclude concessions for underwater antique sites between diving centers and the Ministry of Culture of the Republic of Croatia 


\section{Island Of Prvić/Vodice}

Inhabitants number (20II.): Prvić Luka (164); Prvić Šepurine (239); Vodice (8.875)

\section{Resource And Attractive Base For Diving \\ Climate}

The annual average sea and coastal air temperature is $15.70^{\circ} \mathrm{C}$, and the island is higher for the season. The coldest calendar month in the year is January when the average monthly air temperature in the coastal and offshore is $7.30^{\circ} \mathrm{C}$ and on the island is $8.40^{\circ} \mathrm{C}$, and the warmest month is July with a mean monthly temperature in the coastal and offshore areas of $24.90^{\circ} \mathrm{C}$, and on the islands of $24.40^{\circ} \mathrm{C}$. The sea temperatures are from December to April between IO-I5 ${ }^{\circ} \mathrm{C}$, and from May to November between $15-25^{\circ} \mathrm{C}$.

\begin{abstract}
According to climate predispositions, the diving season could last 6-7 months: from May to November. Given that it is currently $3-4$ months from June to September, it can be concluded that the potential of diving tourism in pre-season and subsection is insufficiently utilized.
\end{abstract}

\section{Underwater}

Among the many diving destinations on the Adriatic, Šibenik's undersea for its natural-geographic characteristics and preservation is certainly one of the most interesting. Proof of space value are numerous protected areas (NP Kornati, significant landscapes of the Žutsko-Septic Group of the Island and Kanal-Luka in Sibenik and I8 ecological network ecological sites). At the entrance to the canal is the Fortress of St. Nikole, built from 1543 to 1547 , whose undersea is interesting for diving.

In the aquarium of the Žutsko-Styptic group of islands can often be seen strictly protected species: good dolphin and chamois. Of the many species of fish, they are often protected: chamois, pagar, kavala, tuna and koraf and strictly protected: sea horse - dugokljunica and drozd. Most of the coastal belt is covered with preserved meadows of sea flower posidonia.
In the NP Kornati due to the long-term protection, the underwater park is characterized by exceptional biodiversity. In addition to the settlements of the Posidonia oceanica, which inhabits most of the shallower (up to 40 $\mathrm{m})$ well-lit moving basins, the most interesting coraligenic habitats are present in the submarine of vertical cliffs rich in various marine species, among which the "forests" of the coral coral large horns and large crabs, hlapa and lobster. There are 352 species of algae ( 13 endemic), three Adriatic sea flora, 22 coral corpses, 177 molluscs, 55 decononavian crabs, 64 blackbirds and 160 species of fish found on the list of known species for the underwater world of the NP Kornati. There is a constant population of good dolphins in the aquatorium of the park, and the sea turtle is often seen.

\section{Šibenik underwater has an extremely favora- ble natural resource base for diving since nu- merous marine areas are protected, provid- ing exceptional biodiversity and making it attractive for diving. \\ Diving Sites}

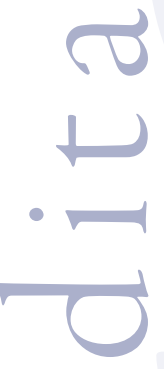

In the Diving Guide to the Submarine of Sibenik-Knin County: Diving in the most amazing part of the Mediterranean (20II), there were 47 diving sites separated from Rogoznica to Kornati and the island of Žutog. Most localities are natural attractions such as underwater reefs, caves, underwater walls, rocks. Locations are mostly located at depths of 6 to $65 \mathrm{~m}$ which allows for a diversified offer for all categories of divers. There were two wrecks from the site: the sinking ship Francesca da Rimini from 1944. in front of the island of Kaprije, which is one of the most attractive wrecks in the Adriatic and woodcutter Zlarin. One of the localities of Eco Dive (near Rogoznica) is well presented: in co-operation with biologists at the site are placed underwater plates with descriptions of species that live there.

Apart from the aforementioned localities presented in the diving guide, local diving clubs have: Wreck Gladijator (Italian steam 
trawler from WWI between Prvić and Zlarin; a plane pike sunk at the Žira (there are only 3 more known underwater locations of such a plane in Europe); amsthorum site from 3st.p.n.e. near Kaprija; sunken German ship in the Sibenik channel.

Ancient Diving Sites

Sites under protection of Ministry of culture RC:

Zirje Island

- Ancient Shipwreck, Z-52

Number of possible permissions: 2

Minimum Annual Fee for One Permission: $5.000,00 \mathrm{kn}$

Special condition: permit holders are obliged to clean the protective net

Kakanj Islan

- Ancient Shipwreck, Z-238

- Ancient Shipwreck, Z-240

Number of possible permissions: 3

Minimum annual fee for one down payment: $5,000.00 \mathrm{kn}$

Island Krapanj

- Ancient Shipwreck, Z-239

- Ancient Shipwreck, Z-242

Number of possible permissions: 3

Minimum Annual Fee for One Permission: $5.000,00 \mathrm{kn}$

Muna, island of Z̈irje

- Ancient Shipwreck Muna, Žirje Z-53

Number of possible permissions: 3

Minimum Annual Fee for One Permission:

$5.000,00 \mathrm{kn}$

Rogoznica

- Ancient Shipwreck, Z-24I

Number of possible permissions: 3

Minimum Annual Fee for One Permission: $5.000,00 \mathrm{kn}$

The submarine destination is characterized by the diversity of localities with an emphasis on a large number of natural sites / attractions. The great attraction is also the vicinity of the NP Kornati which is one of the most famous diving sites in Croatia.

In the Šbenik archipelago there is a significant number of underwater archeological sites that are under the protection of the Ministry of Culture and are issued concessions for diving at those locations. Most diving clubs believe that the concession price is too high, so no one in the area of the Šibenik archipelago has responded to a bid published 2 years ago for the period 2OI4-20I8.

Resource And Attractive Base For NonDiving Activities

Beaches

There are numerous quiet coves and one big pebble beach between Prvić Luka and Šepurina.

There are 2 major pebble beaches in Vodice that abound with entertainment, especially those for children.

\section{Cultural Heritage And Manifestations}

The most important cultural and historical monuments are considered the historical architectural ensemble of Vodice, Prvić Šepurina and Prvić Luka.

Prvić Luka - Sr., ancient sites; St. Roch Grove (antiquity); Lower Banda, Tower Defense (sr.v.); Faust Vrančić's Nightmare (I6th century); Church of Sv. Mary (isth century), Church of Our Lady of Comparison (Isth century); Church of St. Roch (I7th century); The Church of Our Lady (I8th century);

Faust Vrančić Memorial Center is located in Prvić Luka, where visitors can learn about the life and works of this genre, see the collection of models of his invention, and his most significant written works.

In the immediate vicinity of the destination is Šibenik (Cathedral of UNESCO, St.Nicolas fortress) while at a distance for a day trip there are 3 cities with rich cultural heritage and tourist offer (Split-UNESCO, Trogir-UNESCO, The Zadar defense system of Zadar-UNESCO). 
Cultural Heritage And Cultural Attractions

From Ancient Period

The ancient sites and tomb of St. Deadline in Prvic Luka. Ancient locality Pišća in Vodice. The remains of the late antique basilica in Srima.

\section{Natural Heritage}

In the immediate vicinity of the destination are 2 National Parks: Krka and Kornati, and Vransko Lake Nature Park.

\section{Sport and Manifestations}

9 cycling trails in the town of Vodice; kayaking on the sea; windsurfing and smaller classical sailings - gajetama; Nordic walking and hiking through the olive groves and dry terraces in the hinterland of the City of Vodice.

Regatta Jabuka (Novembar - the most popular offshore regatta in Croatia runs sailors for a IIO-mile course of Vodice - Jabuka - Vodice. Regatta is known for the night start and the Mystic Jabuci); Easter Regatta (April); regatta Burtiž (August - regatta of traditional ships moving from Šepurina to the island of Prvić)

\section{Big game fishing}

Gabri Marathon - In October, a recreational mountain-bike marathon is traditionally held in memory of cyclists Gabriele Skočić and his friends, firefighters who died bravely and tragically on the island of Kornat in 2007. Bicycle trails in the hinterland of Vodice run shorter $(27$ $\mathrm{km})$ and longer $(54 \mathrm{~km})$ marathon. This marathon gathers I5O competitors every year from all over Croatia and abroad.

\footnotetext{
The destination has a favorable geopolitical position in relation to some of the most $\mathrm{fa}$ mous Croatian cultural and natural attractions such as UNESCO National Parks or Cultural Heritage which contributes to its tourist attractiveness and can affect the arrival of a segment of recreational divers and those traveling with families and except for diving an interesting and interesting non-diving program
}

As this profile of tourists on holiday with diving is most practiced by sports activities, the offer of active tourism in the destination is considered to be somewhat satisfactory and within which specially attractive sporting events taking place outside of the season such as the Gabriella Marathon or Regatta. which provide the possibility of developing tourism products in pre-season and post season.

Destination Prvić-Vodice has no significant cultural heritage from the antiquity period as well as cultural attractions on this subject.

\section{Accomodation Capacities}

-

According to last available datas from 2014 on the island of Prvic, there is an entity from the branch of Hotel Maestral *** (Prvić Luka) and Hostel Peski (Prvić Luka).

There are 13 subjects from the branch of the hotel $\left(5^{* * * *}, 6^{* * *}, 2^{* *}\right)$, Io campers $\left(\mathrm{I}^{* * *}\right.$, other $*), 2$ hostels and one holiday resort in the area of Vodice.

In the city of Vodice in June 2014, a total of 1,567 subjects were registered, who rent rooms and apartments in households with a total capacity of 11,908 beds. The Prvić Island is represented by 68 households (Prvić Luka 30 households and 468 beds and Šepurina 38 households and 201 beds) - a total of 605 beds.

In the structure of the accommodation capacities of the destination are dominated by private households and hotels of medium category which can position the destination as attractive or passionate divers, mainly ac commodation is not so important to recreational divers and those traveling with families and lower incomes.

\section{Accessibility OfDestination}

Traffic connection

The destination is located in close proximity to two airports: Split / Resnik (sokm), Zadar / Zemunik $(70 \mathrm{~km})$. There are regular transfers by taxi and bus from both ports to Sibenik. Both 
airports have a good connection with all the broadcasting markets throughout the year.

As far as road connections are concerned, the strategic road system of the road system is the Ar Zagreb - Split motorway, which is connected via the node to the Clean Small linking network of the Town of Vodice. The highway runs through the northern part of the town of Vodice.

The island of Prvić is connected to the mainland by two lines from Sibenik and Vodice.

\section{Emitive destination markets}

Statistics for 2016 for Vodice: domestic guests: I 43,399 (overnight stays); foreign guests: 932.852 (nights

Most foreign guests come from Germany, Poland, Slovakia, Slovenia, Czech Republic, Austria, Hungary, Bosnia and Herzegovina. Below $2 \%$ are from Sweden, Italy, France, Switzerland, Norway, Netherlands, Finland, UK

\section{Motives for tourist arrivals}

In the survey conducted in 2014 for the needs of the Tourism Development Strategy of Vodice (2015), according to the motive of the arrival of tourists on the tourist destination of Vodice in the first place, as shown by $62.8 \%$ of surveyed tourists, is swimming, swimming, enjoying in the sun and the sea. Second place $(28.7 \%)$ is new experience, and third (25.5\%) is a sightseeing of nature and national parks. As the main motive for coming to Vodice area, I0.6\% of tourists showed diving. As the motive of the arrival of tourists in the area of Vodice was the possibility of another response to their second motive for vacationing in the City of Vodice, $18 \%$ of surveyed tourists drew diving. From activities involving tourists involved in the destination, even $25.53 \%$ practiced diving. Diving as the main motive for the arrival of German tourists (the most significant emission market of Vodice) was $8.16 \%$, Czech $8 \%$ and Poland $16.67 \%$.

\section{The Vodice area has already been recog- nized as a diving destination on its 3 main tourist market: Germany, Poland and the Czech Republic, and it would be advisable to focus on these markets when creating new products in the field of diving tourism. Especially in the German market, which is the UK's largest European emitive diving market.}

Table 4: SWOT

\section{STRENGHTS}

favorable climatic conditions

- attractive marine flora and fauna such as dolphins and sea turtles

- air and road accessibility of broadcasting markets - the destination has been recognized as a diving few on the broadcasting market

- a large number of antique submarine sites

- a large number of protected areas on the sea

- close to national parks: Kornati, Krka, nature park Vransko jezero

- close proximity to cultural and tourist centers: Split (UNES-

CO), Trogir (UNESCO), Šibenik (UNESCO) and Zadar

\section{WEAKNESSES}

- the absence of a no-take zone

- legal regulations do not support the development of diving (sewage ships)

- diving clubs are not willing to pay diving concessions at underwater archeological sites

- a small number of diving clubs with international certifications

- a small number of ship wrecks

-insufficiently developed offer of active tourism

- lack of international quality accommodation 
- introduction of a no-take zone

- the possibility of changing legal regulations regarding ship seizure

- the possibility of introducing new attractive services at diving centers

- development of attractive all-inclusive offers for divers

- raising the quality of accommodation capacities

- diversification of tourism products is one of the goals of the

Tourism Development Strategy of Vodice with the proposal for

the development of diving centers / diving tourism

\section{Montenegro - Budva}

\section{Diving Tourism In Montenegro}

Diving tourism in Montenegro is not recognized as a special type of selective tourism that has its market and the offer mostly function as an additional sporting activity in the destinations.

The umbrella organization for divers in Montenegro is a diving association, but they are not involved in the promotion of diving tourism but are mainly concerned with related clubs and clubs. The promotion of diving tourism is in the domain of TO (Tourist Organizations) which do not distinguish this aspect of tourism as a special and significant niche in tourist offer (in the Master Plan of Tourism Development in Montenegro by 2020, which is the last strategic document in tourism diving is hardly mentioned). Consequently, Montenegro is not presented as a destination for diving tourism at special diving tourism fairs (ITB in Germany or WTM in the UK).

There is no legal regulation for diving (diving tourism and diving sports are not separated from other diving), so a large number of illegal and incompetent subjects dealing with diving tourism while the control system of areas where the dive is insufficiently developed.

National legislation that in other European countries allows for the development of diving tourism such as scuttling does not exist and it is very difficult to obtain a license for such a thing. There is also no awareness of the introduction of no-take zones that do not allow any human activity except diving and are primarily directed to
- ecological degradation of the underwater (fish catch)

gradual retardation of competition

the growth of other diving Mediterranean destinations

insufficient marketing activity in target markets

the lack of a clearly shaped tourist product

- inability to conclude concessions for underwater antique sites

between diving centers and the Ministry of Culture of the Re-

public of Croatia

the preservation of a fish-based fund that makes the underwater more attractive for diving.

As far as diving standards and certifications are concerned, only a few of the approximately I8 diving clubs in Montenegro have a total of approx. PADI certification, which is the most popular and internationally most prestigious professional certification issued to diving clubs. This greatly impedes the promotion of diving tourism because European tour operators specializing in this tourism sector work exclusively with those diving clubs that have international certificates.

Education of diving staff regarding the interpretation of underwater sites does not exist. The potential of multimedia technologies in the presentation of underwater sites has also not been used at all.

There are around 16-18 diving clubs / centers in Montenegro, all of which offer diving, courses and excursions. The diving season lasts about 4 months, from June till September. Most divers services are bought in July and August when it is high tourist season in Montenegro confirming the fact that diving is rarely tourist's primary motive to arrive at the destination but one of the side activities in the destination.

Montenegro has not been recognized on the major broadcasting markets as one of the existing Mediterranean diving destinations and is not included as a destination on some of the popular web services for the purchase of tourist diving services such as: scubatravel.com; scubatravel.co.uk; divebooker.com; easydivebooking.com.

Most diving centers offer more or less the same services as: diving courses, renting equipment, boat trips, diving. 
Also, most diving centers do not offer package deals.

\section{Budva}

Inhabitants number: 10.918

\section{Resource And Attractive Base For Diving \\ Climate}

The Budva Coast is one of the hottest areas in Montenegro, while the Budva Sea is one of the hottest parts of the Adriatic Sea.

The color of seawater as a whole is blue, which is more intense with increasing depth and salinity. Water supply is different in the years. Thus, during the summer in the south, $33.1 \mathrm{~m}$ in the spring, $31.3 \mathrm{~m}$ in the spring, $30.5 \mathrm{~m}$ in the winter, and $23.8 \mathrm{~m}$ fall. The bathing season on the Budva Riviera starts about Io May and runs until is October.

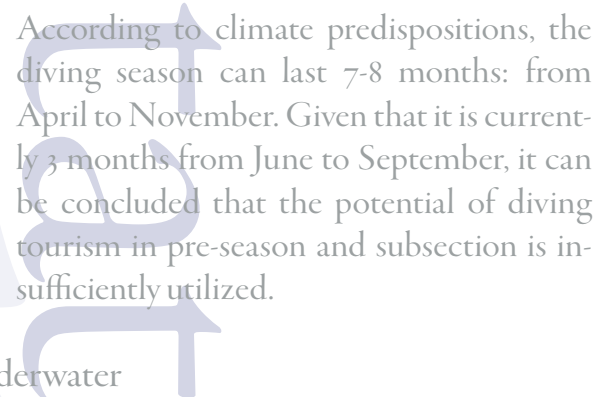

Budva is open to the open sea in its southernmost, warmest and deepest part. The rugged bottom, as it is most often before the Budva Riviera, is rich in plant and animal life. It is covered with green, lime and red algae in which many species of fish live (over 300 species).

\section{Montenegro has no protected area on the sea, which negatively affects the develop- ment of flora and fauna and makes the un derwater less attractive for scuba diving.}

\section{Diving Sites}

Interviewed diving clubs ( 3 out of a total of 7 in the wider Budva area) offer sightseeing submarines on the move from Bokokotor Bay to Bar.

Natural attractions: Location of tunnels, Galiola ridge, Krekavica cave, Posejdon town, rivers Donkova seka, vertical tunnel 'Sirena hole', underwater cave 'Sweet cave', Blue cave, Cape Good Harbor, Podkaplje cave, Cape Mogren, Kraljičina beach; the cave of Mikovic; the cave of Stari Ulcinj; Lighthouse, Skočiđevojka, Školjić, Sveta Neđelja, Katič, Donkova seka, Antun, Čanj.

Flooded ships and planes: Shipwreck 'Patrolla' (1952 military ship); ship wreck 'Tihani' (parachute from 1908) - this is the nor dive site in Montenegro; British Spitfire aircraft; torpedo boat $76 \mathrm{~T}$; patrol boat PBR 512; the ship 'Maria Pompei'; 'Oreste' boat; JNA miners; ship Senta; Destroyer 'Dague' (French WWI warship); gunner from the I8th; parobrod 'Quinto' (19221940); 'Spiridon' ship; French goblin; 'Carola' boat; ship SS Skodra; ship 'Goritia'; JNA in Boka Kotorska Bay, JNA from 1983 near Luštica, minesweeper I 43, Junkers aircraft bomber

Ancient Locations: Amphora Bigovica; amfore $\mathrm{rt}$ Đerana

\section{The Budva submarine is characterized by the abundance and diversity of underwater locations where large quantities of submers- ible ships and aircraft are available, which are the most attractive to divers by all avail- able research. There is also a large number of caves that are most attractive to divers among natural attractions.}

\section{Diving Sites From Ancient Period}

- Rt Platamuni - the site of ancient shipwreck - Kalafat reef - remains of ancient shipwreck without discovered remains of broad

- Trsteno Bay - Remains of Antique Shipwreck

- Bay Jaz - Remnants that point to ancient shipwreck

Of the interviewed diving clubs, only one offers sightseeing on 2 ancient sites: amfore Bigovica; amfore rt Đerana. For diving at the mentioned sites do not have permission because diving on underwater archaeological sites is not legally regulated in Montenegro. Also by exploring diving clubs, diving at such sites is not so interesting to tourists 
as compared to other underwater locations unless the localities are not converted into an underwater archaeological park.

Resource And Attractive Base For NonDiving Activities

Beaches

Budva's beaches by the quality of sand fall into the highest categories. They stretch on $38 \mathrm{~km}$ of indented coastline with many sandy coves, shelter, hills and small islands. There are about 35 sand beaches ( 8 have blue flags - a prestigious international award for quality, standard of service and beach bidding).

\section{Cultural Heritage And Manifestations}

The Old Town - the main sight of Budva is the old town complex surrounded by ancient ramparts. Here is a preserved seaside Citadel dating from the $15^{\text {th }}$ century, located in the southern part of the old town.

Sveti Stefan - an attractive combination of historical and contemporary luxurious ambience and represents the most luxurious resort in Montenegro. Because of its uniqueness, Sveti Stefan is in "National Geographic Traveler" proclaimed one of the "5o Places of a Lifetime".

The Kosmas fortress is located near Budva near the village Brajići, at 800 meters above sea level, Kosmač Fortress. The fortress was built between I84I-1850. And was an Austrian fortress that represented the border between Austria and Montenegro, today is a special place to visit all the tourists who visit Montenegro.

The City Theater is a well-known international event in Europe for 25 years, which usually begins in July and ends in mid-August. It consists of theater performances, concerts of classical music, literary and poetic evenings, art exhibitions.

Every year, the cultural summer in Budva is celebrated by the Music Festival Budva, which is held every year along the ancient Budva walls and which has a number of new hits every year.
Budva has hosted the Great Carnival in May and the "International Dance Festival" in Jun.

For the fans of jazz music, the warm Petrova night was enriched by the Petrovac Jazz Festival which, besides various performances and concerts, holds workshops, exhibitions and other alternative and educational programs.

\section{Cultural Heritage From Ancient Period}

In the center of Budva, near the Old Town, there are remnants of the former antique acropolis and 2 extremely valuable antique cultural objects: the remains of a mosaic floor from the beginning of the $2^{\text {nd }}$ century BC. An urban villa and fragments of the floor mosaic of an early Christian nineteenth-century basilica (late $5^{\text {th }}$ century). These remains are without proper presentation.

The remains of the ramparts with one of the alleys in ancient Budva are located right next to the main street in the basement of a business space and are partly visible but are not adequately presented or marked. In the vicinity of this site are also the remains of stone plastic of a Roman building placed on a small staircase at the end of Ancient Street. Notwithstanding these archeological remains, there is no inscription to give visitors information on artefacts.

The Archaeological Museum (Old Town) has a rich archaeological collection of $2500 \mathrm{ex}-$ hibits, which is also the most beautiful collection of glass from the Roman period in Europe.

\section{Natural Heritage}

2 National Parks: Lovćen; Skadarsko jezero

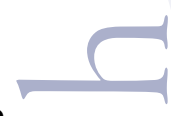

Sport

Sports infrastructure: tennis courts, soccer fields, basketball. Tivtu is building the first golf course in Montenegro.

Walking and biking trails - there are maps produced by the "A \& V Tourism Development Center", where there are I2 selected hiking trails with their characteristics so that the walker can also be easily navigated individually in the Budva hinterland. 
The "Bungee jumping" skyscraper, 40 meters tall, built at the end of the Slovenian beach, has been a real attraction for fans of extreme sports in the past years.

Paragliding - one of the most famous paragliding jets in the Adriatic is located just above Budva, at Brajići, at $760 \mathrm{~m}$ above sea level. An incredible view of the Budva Bay makes this jumper one of the most popular. Extreme climatic benefits - a wind that provides a safe, and also exciting flight, seasickness and panorama of the Budva Riviera, makes paragliding to your favorite extreme sports.

Rafting on the river Tara.

\begin{abstract}
Budva is Montenegro's most popular tourist destination and has a wide range of cultural and sporting activities that make it an even more attractive product for diving tourism, especially considering that $80 \%$ of this market is just a segment of recreational diving and those traveling with families you should also design attractive non-diving programs and activities

This is the advantage of Budva and the im mediate vicinity of the two NPs: Lovćen (37 $\mathrm{km})$ and Skadar Lake $(4 \circ \mathrm{km})$ where you can also dive.

Particular attraction of Budva are sandy beaches (35), which is the specificity of the Møntenegrean sea coast in relation to the entire Adriatic coast of the Adriatic Sea and can be of particular interest to the segment of divers traveling with families.
\end{abstract}

Budva has a significant number of archaeological remains from the antiquity period that are found in the Old Town, but none has been adequately restored and presented. Although the archaeological museum possesses a wealth of antique collections, it has not been modernized in the artifacts' presentation and does not include the multimedia that is needed today in order to apologize to the interesting and complete story of antiquity.

\section{Accomodation Capacities}

According to last available datas from 2015 Budva has 84 accommodation facility; 56,312 beds in 38 large hotels $\left(3\right.$ hotels $5^{*}, \mathrm{I}_{7}$ hotels $4{ }^{*}$, I2 hotels $3^{*}, 5$ hotels 2 *, I hotel I ${ }^{*}$ ); Hotel Garni( 5 hotels $4^{*}, 8$ hotels $3^{*}$, I hotel $2^{*}$ ); i 7 little hotels ( I hotel $5^{*}, 7$ hotels $4^{*}, 6$ hotels $3^{*}, 3$ hotels $\left.2^{*}\right) ; 2$ Apart Hotel ( I hotel $4^{*}$, I hotel $2^{*}$ ); 2 tourist resorts ( I village $4^{*}$, I village $3^{*}$ ); 4 bed and breakfast( 2 pansion $3{ }^{*}$, I pansion $\left.2^{*}, \mathrm{I}^{*}\right)$; 55 accommodation units / I35 beds in tourist apartments; 17,857 rooms for rent; I camp; I hostel; 3 resorts.

$$
\begin{aligned}
& \text { Budva as the leading tourist destination of } \\
& \text { Montenegro is characterized by a very good } \\
& \text { and varied offer of accommodation capaci- } \\
& \text { ties. } 60 \% \text { of all hotel facilities in Montene- } \\
& \text { gro are concentrated in Budva, where a large } \\
& \text { number of high category hotels ( } 4 \text { and } 5^{*} \text { ) } \\
& \text { are present. This kind of hotel offer can at- } \\
& \text { tract market segments of leisure divers and } \\
& \text { divers who travel with families who gener- } \\
& \text { ally have high income research and prefer } \\
& \text { high-quality or luxurious accommodation. } \\
& \text { A large number of hotels also point to fa- } \\
& \text { vorable opportunities for the formation of } \\
& \text { tourist products in pre-season and post-sea- } \\
& \text { son. }
\end{aligned}
$$

\section{Accessibility OfDestination}

\section{Traffic connection}

Airport of Podgorica $(65 \mathrm{~km})$ - Avio traffic on regular routes is maintained by Montenegro Airlines, Air Serbia, Adria Airways, Aeroflot, Turkish Airlines, Austrian Airways, Alitalia, Smartwings, ... and during the summer and numerous charter companies. Flights and 3 low-cost airlines: RyanAir and Wizair, Easyjet, which in recent years have introduced a number of new flights to Western European destinations. The airport and Budva are not connected by regular road transport.

Tivat $(20 \mathrm{~km})$ - There are very few flights during the season although there are regular regular flights to several international destinations. During the summer season there are many char- 
ter flights through which Tivat is connected with many cities in the world.

Dubrovnik / Čilipi $(75 \mathrm{~km})$ - There is no transport from the airport to Budva, but Dubrovnik and Budva are connected by bus line that goes from the bus station to Dubrovnik.

\section{Emitive destination markets}

Neighboring markets, with Serbia as the dominant market, realized together 3.7 million registered nights in 2007.

Nights made by foreign tourists account for up to $46 \%$ in the EU and up to $20 \%$ in Russia, which represents the largest single market for Montenegrin tourism.

Since geographically very far from the major European diving markets for Montene- gro, Montenegro is primarily an airline destination, so the planning and launch of new tourist products is closely related to those markets that are available on the plane.

Budva is located close to both Montenegrin airports, which are best connected with Russia and Serbia, which are also the 2 largest markets for Montenegrin tourism.

There are lines by a series of major European cities (UK, Germany, Sweden ...). The connection with Western European destinations is noticeably weaker outside the season, making it difficult to plan diving tourism in pre-season and post-season.

Table s: SWOT

\section{STRENGHTS}

\section{WEAKNESSES}

- favorable climatic conditions

- variety of underwater locations with a large number of wrecks - airspace availability of several broadcasting markets - developed diving tourism as an additional offer in the destination

- cultural heritage from the ancient times

- close proximity to national parks: Lovcen, Lake Skadar - close proximity to cultural and tourist centers: Kotor (UNESCO), Dubrovnik (UNESCO),

- a large number of attractive sandy beaches, of which 8 have a blue flag

- good and varied quality of existing hotel capacities from affordable to super-luxurious

- a wide variety of sport and adrenaline tourism activities

\section{OPPORTUNITIES}

- the possibility of changing legal regulations regarding ship seizure and no-take zones

- the possibility of introducing new attractive services at diving centers

- conservation and valorisation of ancient 'in situ' shopping malls - construction of the highway and introduction of additional outboard air lines

- development of diving centers in the direction of an all-inclusive offer for divers

- the trend of ecological tourism (recognized in the Master Plan for Tourism Development in Montenegro by 2020, suggesting Montenegro's positioning on tourist markets as an 'ecological state' under the slogan Wild Beuty) -worse aviation connection out of season

absence of protected marine areas

- Montenegro is not recognized as a diving destination on the broadcasting markets

- legal regulations do not support diving (no-take zones)

- a small number of prepared underwater archaeological sites for sightseeing

diving on archaeological sites is not legally regulated

- a small number of diving clubs with international certifications

-ancient heritage in the destination is not valorized

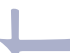
)

(1)

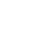




\section{Povzetek}

Skoraj vsi največji trgi za potapljaški turizem v Evropi, denimo Združeno kraljestvo, Nemčija, Francija, Italija ali Avstrija, so se že odzvali na tržišča destinacij ATAS, ki omogočajo promocijo potapljaškega turizma na Jadranu na teh trgih, kjer Jadransko morje že zdaj velja za priljubljeno turistično destinacijo. Glavna pomanjkljivost je v tem, da nacionalni turistični uradi, ki so glavna turistična promocija v Sloveniji, na Hrvaškem in Črni gori, ne prepoznajo potapljaškega turizma kot posebne vrste selektivnega turizma, ki ima svoj trg, zato potapljaška ponudba deluje le kot dodatna športna dejavnost destinacije in le redko kot glavni namen obiska. V primerjavi z najbolj priljubljenimi potapljaškimi destinacijami v Evropi in v tujini je prednost destinacije ATAS lahko geografska bližina večine trgov, zaradi česar je Jadran atraktiven kraj potapljanja za krajše izlete skozi vse leto in je lahko še posebej privlačen za strastne potapljače. Glede na dejstvo, da so vse destinacije ATAS znane turistične destinacije $\mathrm{z}$ razvito turistično ponudbo in bogate z naravno in kulturno dediščino, so lahko še posebej zanimive za rekreativne potapljače in tiste, ki potujejo z družinami ali v paru. Primerjalne analize in SWOT analize destinacij ATAS so pokazale, da je uvedba območij prepovedi uporabe, izkrcanje ladij, izdelava paketov za vse potnike, ki vključujejo nekaj jadranskih destinacij, izboljšanje predstavitve potapljaških točk in poudarjanje potapljaške specifičnosti Jadrana v primerjavi z drugimi destinacijami lahko vodilo za boljši razvoj potapljaškega turizma na Jadranu.

Jadransko morje je bogato s podvodno antično dediščino, ki lahko predstavlja zanimivo potapljaško ponudbo. Na Hrvaškem je večina lokacij pod zaščito Ministrstva za kulturo, potapljanje pa zahteva plačano koncesijo, ki je običajno visoka, zato so te lokacije redko vključene v potapljaško ponudbo. V Črni gori večina območij ni raziskana in ostaja nezaščitena, tako da so ta območja ogrožena in večinoma niso vključena v potapljaško ponudbo, saj potapljanje na podvodnih arheoloških najdiščih v Črni gori ni zakonsko urejeno.

$\mathrm{Na}$ Jadranu sta le dva urejena podvodna arheološka par$\mathrm{ka}$, in sicer Simonov zaliv v Izoli in podvodni zgodovinski park v Malem Lošinju. Razvoj novih podvodnih parkov lahko varuje podvodno dediščino in razvija nove atraktivne kraje potapljanja na Jadranu.

\section{Summary}

Almost all biggest emitive markets for scuba tourism in Europe like UK, Germany, France, Italy or Austria are already emitive markets for ATAS destinations that makes promotion of diving tourism in Adriatic on those markets easier because Adriatic sea is already perceived as popular tourist destination. The major disadvantage is that National tourist offices that are the main body for tourist promotion in Slovenia, Croatia and Montenegro do not recognize diving tourism as a special type of selective tourism that has its market so the diving offer function only as an additional sport activity in destinations and rarely as a main purpose of coming to the Adriatic sea. When compared to the most popular diving destinations in Europe and abroad ATAS destination's advantage can be geographical proximity to most of the broadcasting markets making Adriatic attractive diving destination for shorter trips throughout the year that can be especially attractive to passionate divers. Given the fact that all ATAS destinations are also known tourist destinations with developed tourist offer and rich with natural and cultural heritage they can be especially interesting for recreational divers and those travelling with families or couples. Benchmarking analyses and SWOT analyses of ATAS destinations showed that introduction of no-take zones, scuttling of ships, creation of all inclusive packages for divers that include couple Adriatic destinations, improvement of presentation of diving sites as well as emphasizing the diving specificity of the Adriatic in relation to other destinations can be taken as guidelines for better development of diving tourism in the Adriatic.

Adriatic sea is rich in underwater ancient heritage that can present interesting diving offer. In Croatia most of sites are under protection of Ministry of Culture and diving there require a paid concession which is usually to high for diving clubs so those sites are rarely included in their diving offer. In Montenegro most of the sites are not explored and unprotected so those sites are under threat of thieves and mostly not included in diving offer since the diving on underwater archaeological sites is not legally regulated in Montenegro.

The only two underwater archaeological parks in Adriatic are San Simon in Izola and underwater Historic Park in Mali Lošinj. Development of new underwater 
parks can protect underwater heritage and develop new attractive sites for diving in the Adriatic.

\section{Bibliography}

CBI Product Factsheet: Dive tourism from Europe. The Hague: CBI Ministry of Foreign Affairs, 2015.

Kipreos, George, Pantelis Konstantinakos, Ioanna Anagnostopoulou, Anastasia Perrea and Stylianos Kaprinis. Pavlopetri, the World's Oldest Submerged City: Analysis of Dive Tourism Perspectives Development in the Region through SWOT Anaylsis. Journal of Investment and Management 5, no. 6. (2016): 199-205.

Master plan to support sustainable diving industry in Malta. San Gwann: Adi Associates Environmental Consultans, 2011.

Noćenja turista u kolektivnom smještaju smještaju u Crnoj Gori. Podgorica, Zavod za statistiku Crne Gore MONSTAT, 2015.

Program razvoja održivog turizma grada Mali Lošinj. Mali Lošinj: Institut za turizam, 2013.

Smještajni kapaciteti, Avgust 2ors. Podgorica, Zavod za statistiku Crne Gore MONSTAT, 2015.

Strategija razvoja inovativnog turizma grada Sibenika 2015.-2020. Šibenik: Institut za turizam, 2015.

Strategija razvoja slovenskega turizma 20I2.20I6. Ljubljana: Vlada Republike Slovenije, 2012.

Strategija razvoja turizma Republike Hrvatske do 2020. Zagreb: Vlada Republike Hrvatske, 2013.

Strategija razvoja turizma u Crnoj Gori do 2020.g. Podgorica: Ministarstvo turizma i zaštite životne sredine, 2008.

Strategija razvoja turizma v obcini Izola 20092015. Ljubljana: Hosting Consulting, 2009. Strategija turističkog razvoja grada Vodice. Vodice: Konzulting MILI I PETAR, 2015.

Strateški plan razvoja turizma Kvarnera sa strateskkim ioperativnim marketing planom
20I6.-2020.g. Opatija, Zagreb: Fakultet za menadžment u turizmu i ugostiteljstvu: Institut za turizam, 2016.

Žuljević, Ante, Aleksandar Barić-Sandro, Emil Lemac, Tina Dragutin, Hrvoje Zekanović, Sara Kaleb, Vedran Nikolić, Martina Markov Podvinski, Vladislav Mihelčić and Anita Babačić Ajduk. Ronjenje u najčudesnijem dijelu Sredozemlja Ronilački vodičpodmorjem ŠibenskoKninske Županije. Šibenik: Javna ustanova za upravljanje zaštićenim područjima i drugim zaštićenim prirodnim vrijednostima na području Šibenskokninske županije, 201 I. 